九州大学学術情報リポジトリ

Kyushu University Institutional Repository

\title{
Microfossil Assemblages from the Late Jurassic to Early Cretaceous Nikoro Pelagic Sediments, Tokoro Belt, Hokkaido, Japan
}

Okada, Hakuyu

Faculty of Sciences, Kyushu University

Tarduno, John A.

Department of Geophysics, Stanford University

Nakaseko, Koj i ro

Formerly Institute of Geological Sciences, Osaka University

Nishimura, Akiko

Formerly Institute of Geological Sciences, Osaka University

他

https://doi.org/10.5109/1546555

出版情報：九州大學理學部紀要：Series D, Geology. 26 (3)，pp.193-214，1989-12-20. Faculty of Science, Kyushu University

バージョン：

権利関係 : 
Mem. Fac. Sci., Kyushu Univ., Ser. D, Geol., Vol. XXVI, No. 3, pp. 193-214, text-figs. 1-11, tables 1-4, plates 30-34. December 20, 1989

\title{
Microfossil Assemblages from the Late Jurassic to Early Cretaceous Nikoro Pelagic Sediments, Tokoro Belt, Hokkaido, Japan
}

\author{
Hakuyu OKADA, John A. TARDUNO*, Kojiro NAKASEKO**, \\ Akiko NISHIMURA**, William V. SLITER*** \\ and Hisatake OKADA****
}

\begin{abstract}
The Tokoro Belt in Hokkaido constitutes one of the major ophiolitic belts in the Japanese Islands. In order to clarify the origin of the Tokoro ophiolitic rocks which are represented by the Nikoro Group, new micropaleontologic data of the Nikoro pelagic sediments are presented in this paper as regards radiolarians, calcareous nannofossils and foraminifers.

The results show that (1) the age of the Nikoro Group ranges from the Kimmeridgian to the early Albian, and (2) the Nikoro pelagic rocks were deposited in a seamount environment near an oceanic ridge in the paleoequatorial productive region, where the paleodepth was about $1000 \mathrm{~m}$ and above the CCD.
\end{abstract}

\section{Introduction}

The Tokoro Belt in Hokkaido (Fig. 1) is one of the major ophiolitic belts in the Japanese Islands. Full understanding of the geology and tectonic history of the Tokoro Belt is very important for deciphering the geological evolution of the northwestern Pacific (OKADA, 1982). Consequently it is natural that a number of studies on the geology and tectonics of the Tokoro Belt have been done and are being carried on (for example, BAMBA, 1984; SAKAKIBARA et al., 1986; TARDUNO et al., 1988, and others).

Based on these previous studies, in this paper we intend to clarify the origin of the ophiolitic rocks in the Tokoro Belt. For this purpose we present new micropaleontologic data on the age and depositional environment of the pelagic sediments from the Tokoro Belt. In particular, we described fossil assemblages of radiolarians, foraminifers and calcareous nannofossils from the Tokoro Belt.

Paleomagnetic data from these sediments will be presented separately.

\section{Geologic Setting of the Tokoro Belt}

The Tokoro Belt consists of a Late Jurassic to Late Cretaceous sedimentary

* Department of Geophysics, Stanford University, Stanford, California 94305

** Formerly Institute of Geological Sciences, Osaka University, Toyonaka 560

*** U.S. Geological Survey, Menlo Park, California 94025

**** Department of Earth Sciences, Yamagata University, Yamagata 990

Manuscript received July 27, 1989 


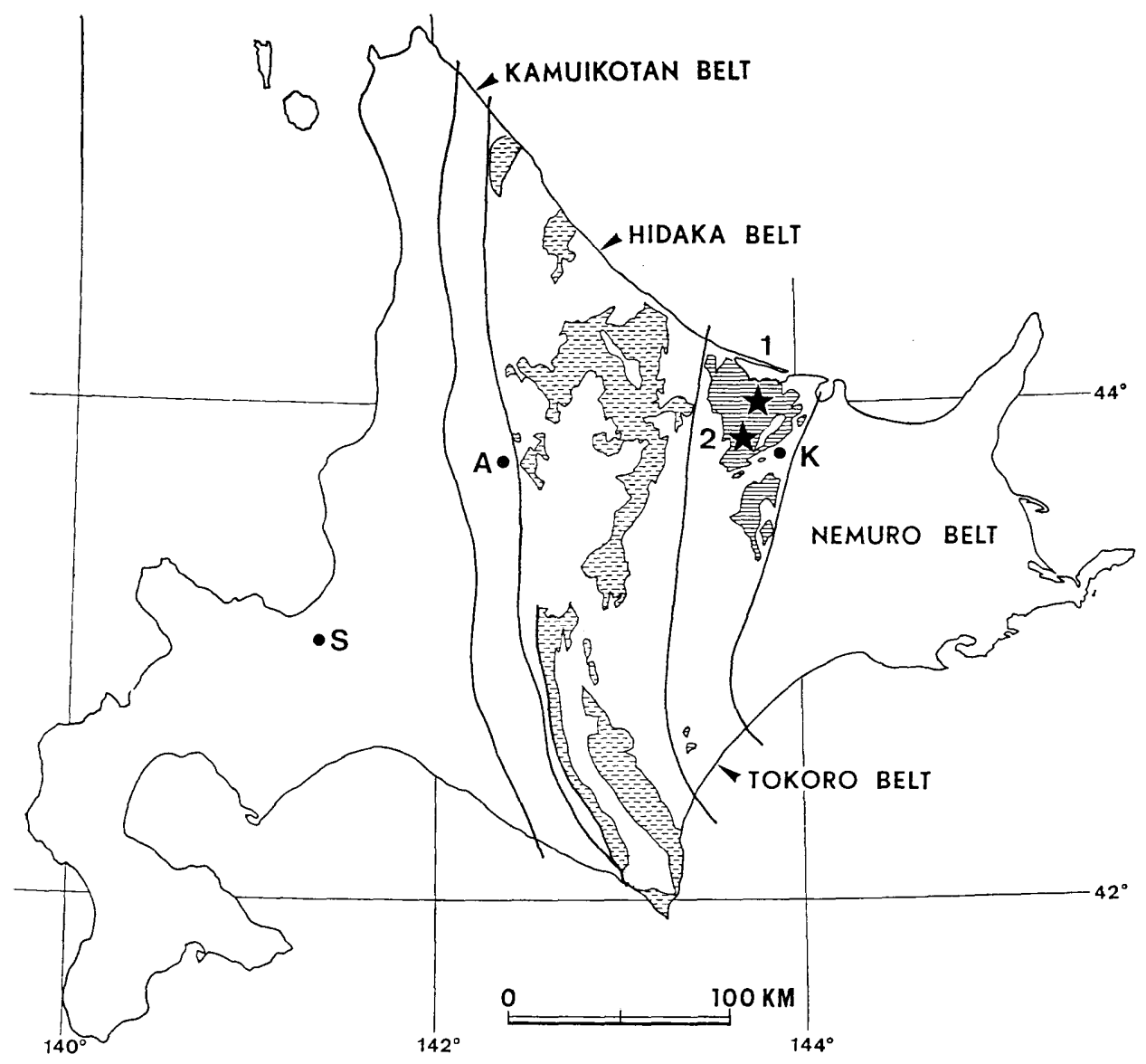

Fig. 1. Index map of Hokkaido showing the distribution of the Tokoro, Hidaka and Kamuikotan Belts. Star marks indicate the study areas: $1=$ Chirai Quarry and 2=Misato Cave. A: Asahikawa, S: Sapporo and K: Kitami.

complex of greenstone, chert, limestone, and terrigenous rocks. These rocks are stratigraphically subdivided into three units, Nikoro, Saroma, and Yubetsu Groups in ascending order. The geologic map of these units is shown in Fig. 2.

The Nikoro Group is characterized by ophiolite suites composed of alkali basalt mostly with pillow structure, hyaloclastite, chert and micritic limestone, ranging in age from Late Jurassic (Kimmeridgian-Tithonian) to Early Cretaceous (Berriasian-Aptian) (KIMINAMi et al., 1983; IwATA et al., 1983). The thickness of the Nikoro Group is at least $4000 \mathrm{~m}$.

The Nikoro greenstone is composed of ultramafic cumulates, dolerite, basalt, trachyte and alkali rhyolite. These alkali basaltic rocks are similar to mid-oceanic ridge basalts in their $\mathrm{Ti} / \mathrm{V}$ ratios rather than intraplate basalts and are considered to have originated from alkali basalt magmas generated at a hot spot near an oceanic ridge (SAKAKIBARA et al., 1986). The Nikoro greenstone was subjected to regional metamorphism ranging from the zeolite facies through the prehnite-actinolite facies (SAKAKIBARA et al., 1986). 


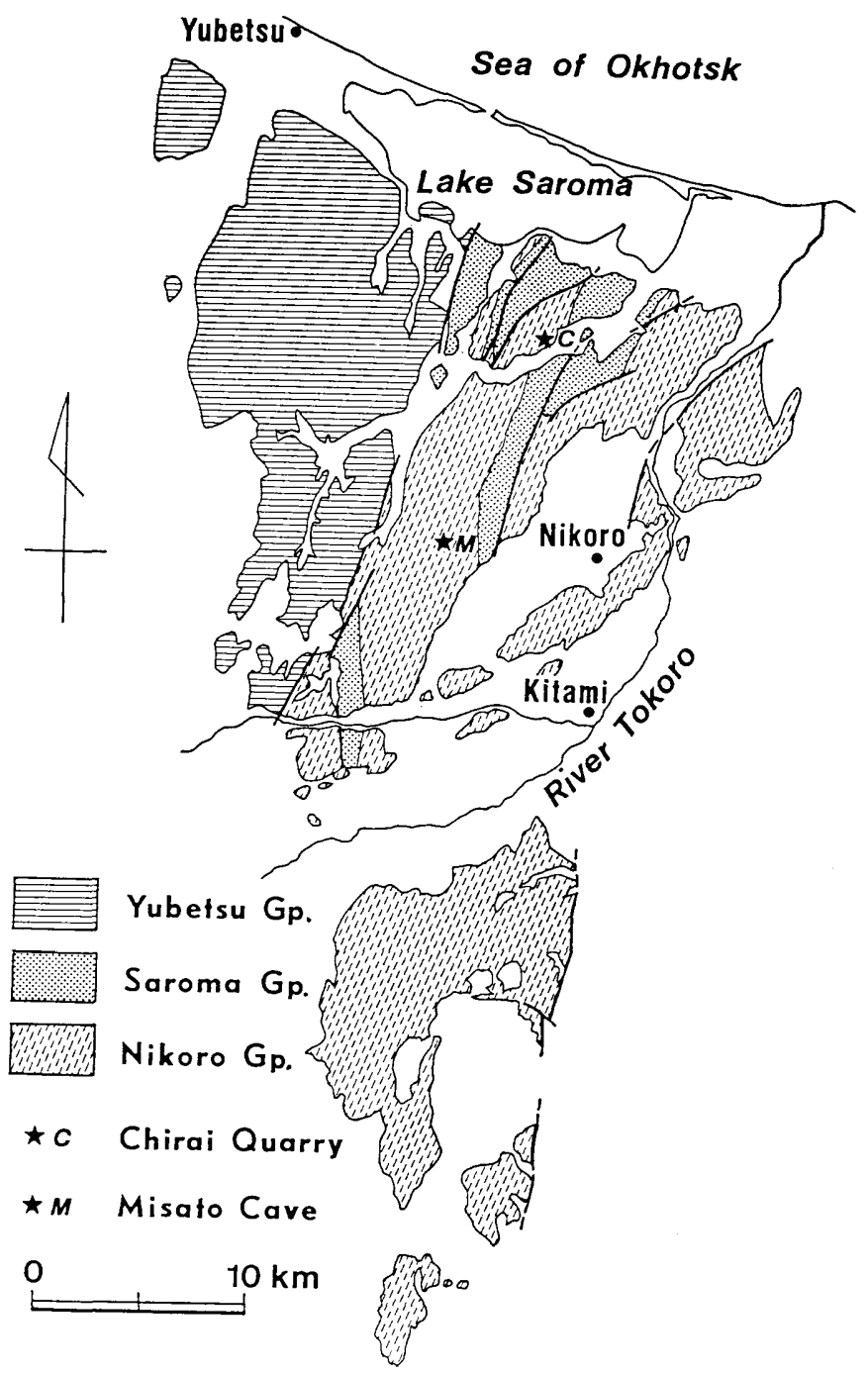

Fig. 2. Geologic sketch map of the northern Tokoro Belt showing the position of the Chirai Quarry and the Misato Cave (modified from SAKaKIBARA et al., 1986 and TAJIKA, 1988).

The Saroma Group, unconformably overlying the Nikoro Group, comprises conglomerate in the basal part, sandstone in the lower, alternation of sandstone and shale in the middle and mainly shale in the upper, attaining more than $2000 \mathrm{~m}$ in thickness. Sandstones are mostly turbidites and are rich in acidic to intermediate volcaniclastic debris (KIMINami and Kontani, 1983; Kontani et al., 1986). Conglomerates contain clasts of andesitic (partly rhyolitic) and monzonitic rocks (SAKAKIBARA et al., 1986).

Coniacian to Santonian radiolarians were reported from the Saroma Group (IWATA et al., 1983). In addition, an inoceramid comparable to Inoceramus 
schmidti MICHAEL of Campanian age was found in the lowermost part of the Saroma Group (SAKakibara and TANAKA, 1986).

The Yubetsu Group is separated by faults from both the Nikoro and Saroma Groups and consists mostly of pelagic or hemipelagic shales, turbidite sandstones and conglomerates (TAJIKA, 1988). Exposed sequences are always separated from each other by reverse faults and individual sequences are tectonically repeated. Manganese spherules were found in red shales (SAKAKIBARA et al., 1986; TAJIKA, 1988). Sandstones are rich in andesitic clasts (Kontani and Kiminami, 1980). Gravels of conglomerates consist of chert, sandstone, andesite, basalt, granite and so on. The thickness of the Yubetsu Group appears to be more than $10 \mathrm{~km}$, but the actual thickness of the Group is unknown owing to tectonic repetition. Radiolarian assemblages from the Yubetsu Group indicate an age of middle Campanian to early Maastrichtian (TAJIKA, 1988).

Tectonic and depositional environments of the Tokoro rocks are interpreted as follows, according to SAKAKIBARA et al. (1986) and TAJIKA (1988): The Nikoro Group is represented by oceanic sediments and seamount rocks formed near an oceanic ridge in Late Jurassic to Early Cretaceous time. The Nikoro seamount rocks were metamorphosed to some extent during subduction beneath the paleo-Okhotsk land. The Saroma Group unconformably covered the Nikoro Group as forearc basin deposits in Late Cretaceous time. Subsequently, the Yubetsu Group was formed as trench-fill deposits which were then incorporated into an accretionary prism.

\section{Studied Sections}

For the micropaleontological investigations of the Tokoro Belt, over 10 limestone localities were visited, but suitable sections for micropaleontological studies were found only at two sites, Chirai Quarry and Misato Cave, both in the Nikoro Group (Figs. 1, 2). Limestones from other localities were too strongly recrystallized.

Lithologic and stratigraphic features at Chirai and Misato are as follows:

\section{Chirai Quarry}

The Chirai Quarry is located about $6 \mathrm{~km}$ east of the town of Saroma, south of Lake Saroma (Figs. 2, 3). Excellent exposures are observable at the quarry operation area (Fig. 4), but outcrop conditions undergo continuous change due to quarrying. The quarry exposures are broken into blocks by faulting, but the original bedding is easily distinguished (Figs. 5, 6). Seven lithologic columns

\section{Explanation of Plate 30}

Thin-section photomicrographs of the micritic limestone from the Chirai Quarry. Plane polarized light. Scale bar $=1 \mathrm{~mm}$.

Fig. 1. Calcite-veined, radiolaria-rich, gray-colored micrite. Sample T0-70.

Fig. 2. Calcite-veined, foram-common, radiolaria-rich, pink-colored micrite. Sample T3A-1. 

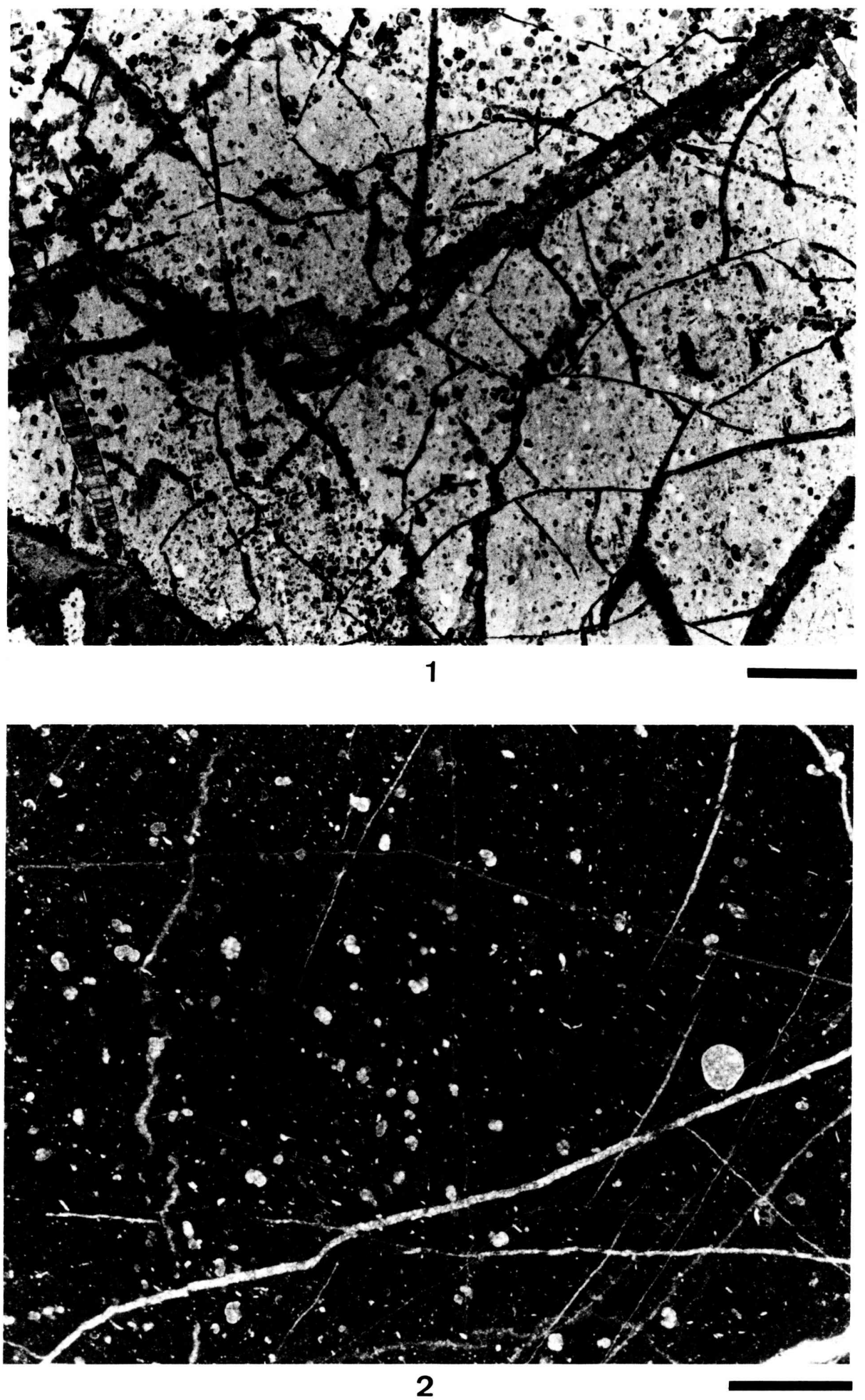

H. OKADA et al.: Microfossil Assemblages from the Nikoro Pelagic Sediments 


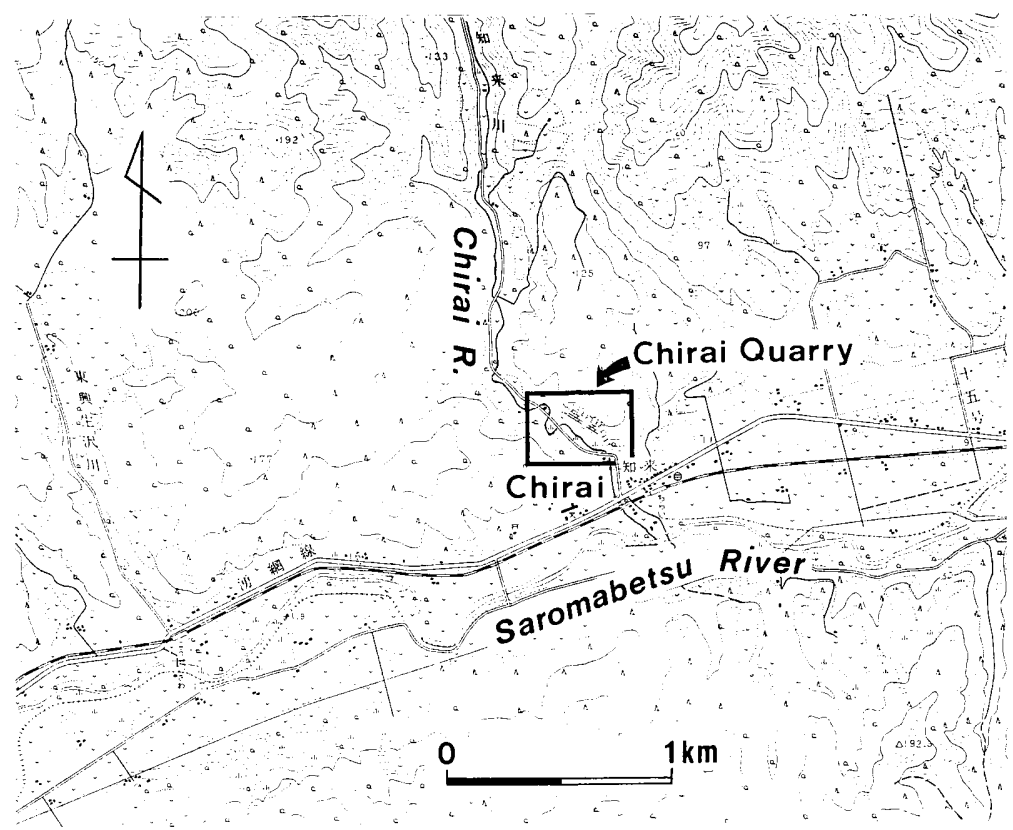

Fig. 3. Index map showing the location of the Chirai Quarry.

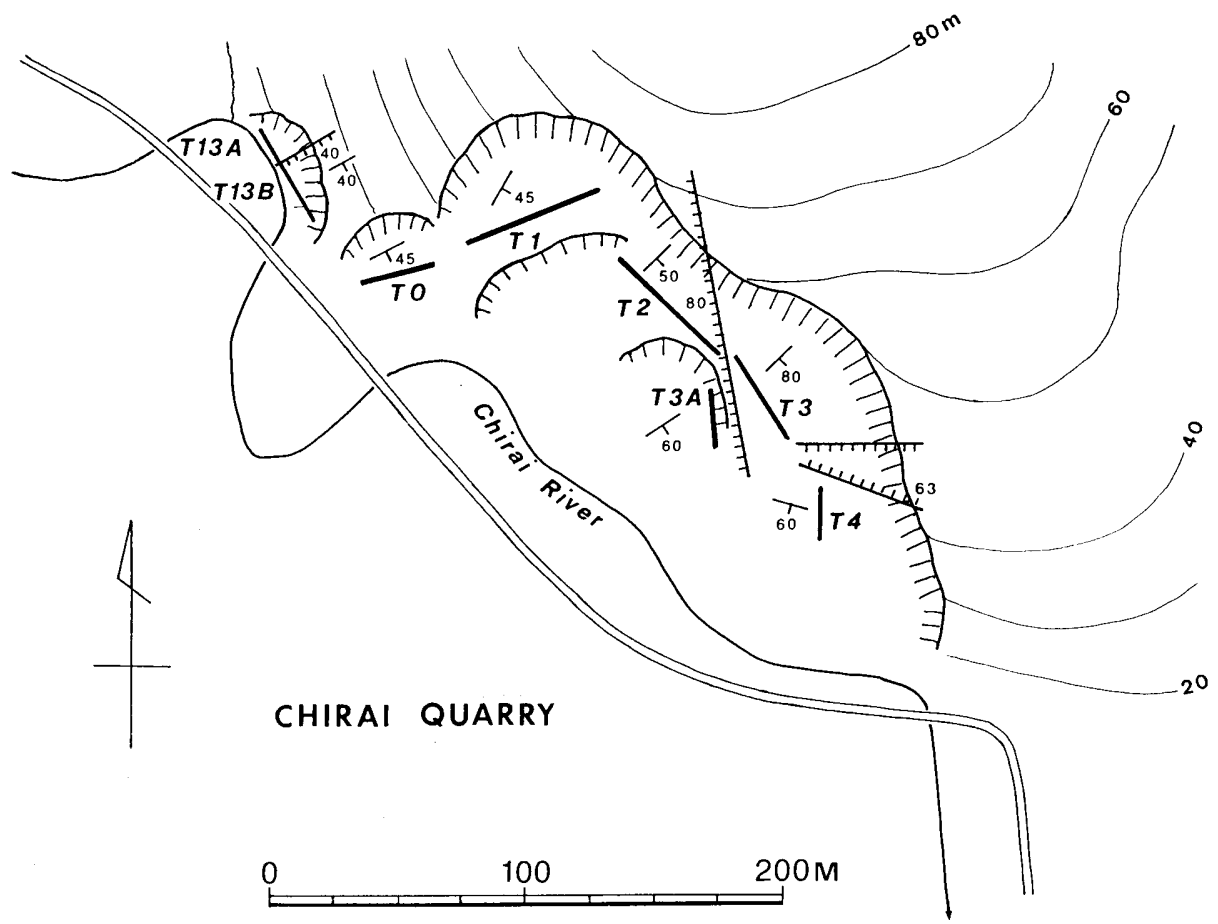

Fig. 4. Chirai Quarry exposures showing the studied sections (thick lines). 


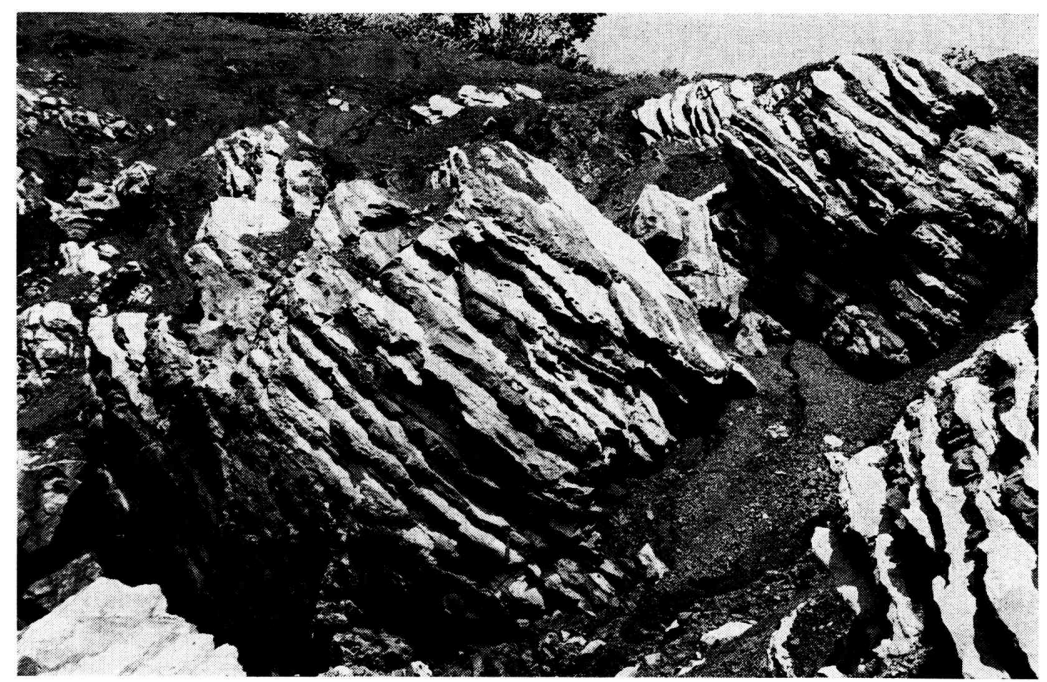

Fig. 5. Outcrop of alternated micrite and chert at the top part of the $\mathrm{T} 3$ block of the Chirai Quarry.

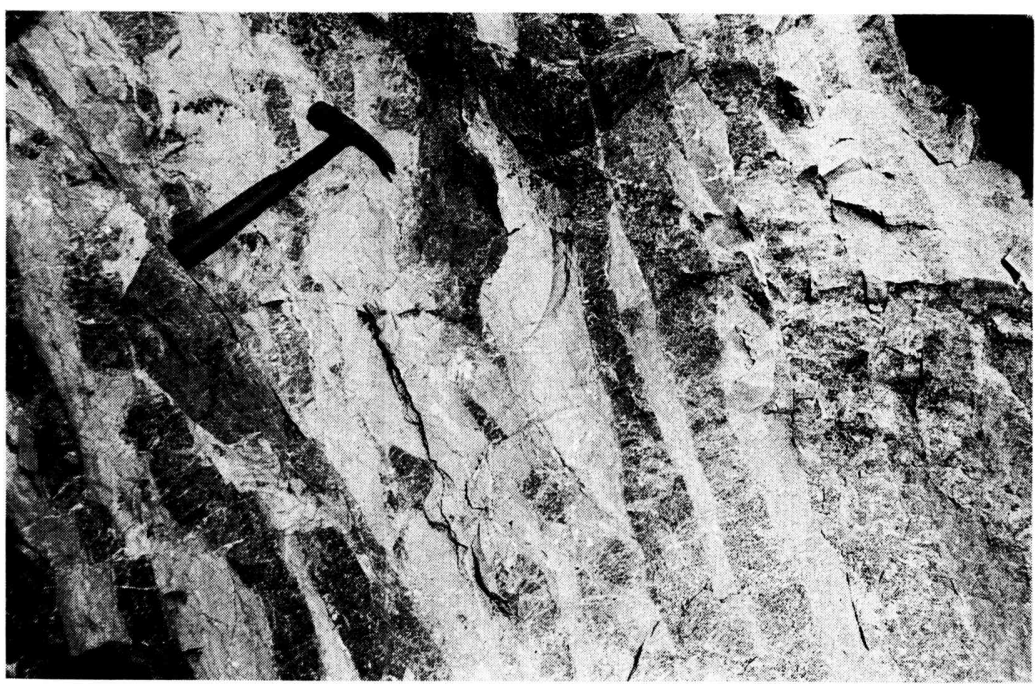

Fig. 6. Photograph showing the occurrence of replacement chert (dark-colored part) interbedded with micrite (light-colored part). $\mathrm{T} 2 \mathrm{~A}$ block of the Chirai Quarry.

were prepared for these blocks, as shown in Figs. 7 and 8. Gray to pink micritic limestones (Pl. 30) are rhythmically interbedded with replacement chert in most of the blocks. The limestone usually bears stylolitic structures and calcite veinlets (Pl. 30), and is accompanied by red, bedded, radiolarian chert (5-10 cm-thick bedded) sequences ( $\mathrm{T} 0, \mathrm{~T} 3 \mathrm{~A}$ ). Bedded chert is sometimes intercalated with films or thin layers of greenish tuff. The T 13A, B sections are characterized by weathered, green, basic tuff at the base (Fig. 8). Replacement chert interbedded with limestone beds is ribbon-like, lenticular, spheroidal and irregular in 
shape (Fig. 6).

About 30 samples from sections $\mathrm{T} 0, \mathrm{~T} 3, \mathrm{~T} 3 \mathrm{~A}, \mathrm{~T} 13 \mathrm{~A}$ and $\mathrm{T} 13 \mathrm{~B}$ were studied for radiolarians, foraminifers and calcareous nannofossils.

\section{Misato Cave}

The Misato Cave is situated about $12 \mathrm{~km}$ west of the town of Nikoro (Fig. 9). Two limestone bodies were investigated, which are $\mathrm{T} 12$ and $\mathrm{T} 12 \mathrm{~A}$. The $\mathrm{T} 12$ section is characterized by light gray micritic limestone (about $20 \mathrm{~cm}$ thick) interbedded with dark gray and red replacement chert (less than $15 \mathrm{~cm}$ thick). Near the top of the section $\mathrm{T} 12$ beds of chert breccia are intercalated and are cemented with fine grained lime-mud (Fig. 10).

The section $\mathrm{T} 12 \mathrm{~A}$ is also characterized by alternating beds of light gray micritic limestone and dark gray replacement chert, similar in lithology and mode of occurrence to those of the section $\mathrm{T} 12$, but altered basalt is observed at the top of the section (Fig. 10).

About 10 samples from the sections $\mathrm{T} 12$ and $\mathrm{T} 12 \mathrm{~A}$ were examined for micropaleontology as mentioned in the Chirai sections.

\section{Paleontology}

\section{A. Radiolaria}

1. Chirai Quarry

About 30 chert and limestone samples from the sections $\mathrm{T} 0, \mathrm{~T} 1, \mathrm{~T} 2, \mathrm{~T} 3$, $\mathrm{T} 3 \mathrm{~A}, \mathrm{~T} 4, \mathrm{~T} 13 \mathrm{~A}, \mathrm{~T} 13 \mathrm{~B}$ in the Chirai Quarry were examined for radiolarians. Generally speaking, the sections $\mathrm{T} 13 \mathrm{~A}$ and $13 \mathrm{~B}$, which represent the lowest stratigraphic units in the quarry (Fig. 11), yield abundant radiolarians, but they are either rare in occurrence or poor in preservation in samples from other sections. Radiolarian assemblages only from the sections $\mathrm{T} 0, \mathrm{~T} 3 \mathrm{~A}, \mathrm{~T} 13 \mathrm{~A}$ and $\mathrm{T}$ 13B were successfully identified. The faunal characteristics in each section are described as follows:

a. Section $T O$ (Fig. 7)

Samples T 0-50, -180 185 and -220 were examined, but radiolarian fossils are rather few in occurrence. Throughout these samples, the Sphaerostylus lanceola group is most common, and Triactoma(?) sp., Cinguloturris cf. carpatica, Archaeodictyomitra sp. are rarely found (Table 1).

b. Section T $3 A$ (Fig. 7)

Seven samples T 3A-5, -15, -200, -300, -400, 500 and 630 were checked. From only two samples $\mathrm{T} 3 \mathrm{~A}-15$ and -200 radiolarian fossils were found. Identified species are as follows: in sample T-3A-15, Zhamoidellum(?) sp., Sethocapsa(?) sp., Pseudodictyomitra(?) sp. and so on; in sample T 3A-200, Archaeospongoprunum(?) sp., Crucella(?) sp., Archaeodictyomitra sp. etc. (Table 1).

c. Section T13A (Fig. 8)

Three samples $\mathrm{T} 13 \mathrm{~A}-80,-480$ and 650 were examined, of which samples $\mathrm{T} 13 \mathrm{~A}-480$ and 650 contain abundant well-preserved radiolarians. In sample $\mathrm{T}$ 13A-80 radiolarians are rather few in occurrence, in which Zhamoidellum 


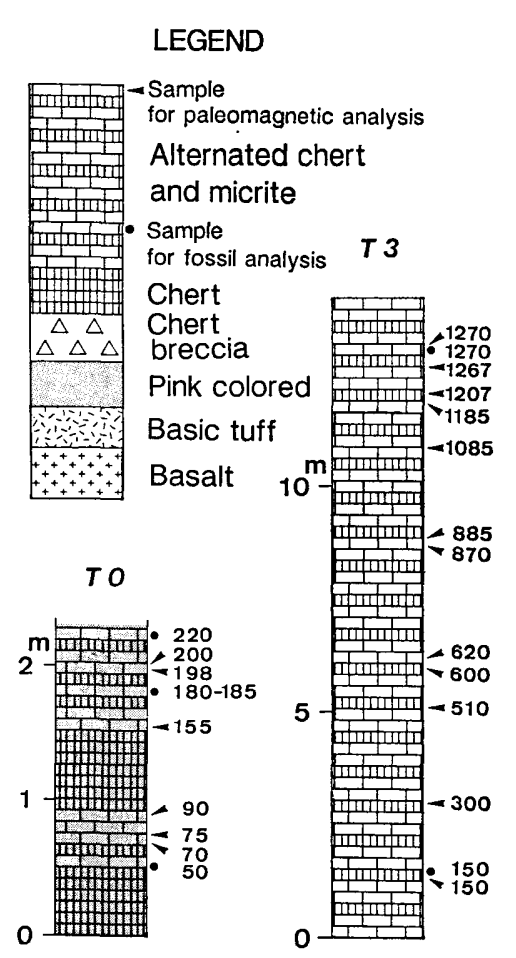

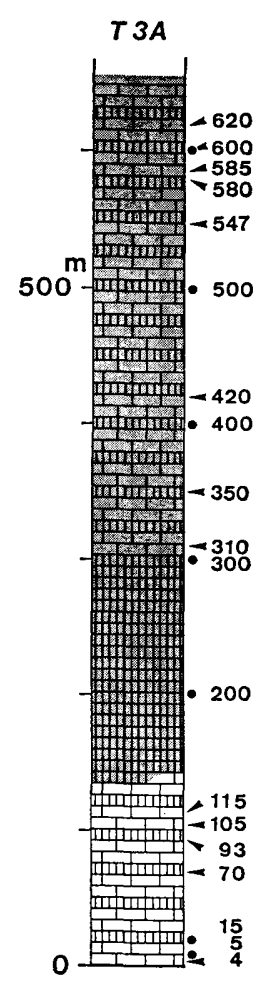

Fig. 7-1.

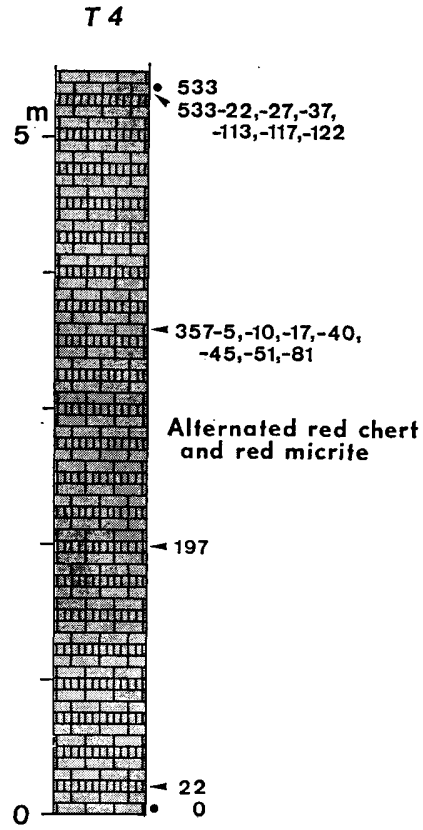

Fig. 7. Lithologic columns from the Chirai Quarry showing the stratigraphic positions of the examined samples. For the positions of the sections $\mathrm{T} 0, \mathrm{~T} 1$, $\mathrm{T} 2, \mathrm{~T} 3, \mathrm{~T} 3 \mathrm{~A}$ and $\mathrm{T} 4$, refer to Fig. 4.

Table 1. Radiolarian assemblages from Sections T0 and T3A from the Chirai Quarry

\begin{tabular}{|l|cccccc|}
\hline \multicolumn{1}{|c|}{ sample number } & T0 & T0 & T0 & T3 & T3 & T3 \\
species & & $\begin{array}{c}180 \\
\text { I }\end{array}$ & & A & A & A \\
\hline Archaeodictyomitra sp. & 50 & 185 & 220 & 15 & 200 & 300 \\
Archaeospongoprunum (?) sp. & + & + & & & + & \\
Cinguloturris cf. carpatica & & & + & & + & + \\
Crucella (?) sp. & & + & & & & \\
Paronaella sp. & & & & & + & \\
Pseudodictyomitra (?) sp. & + & + & & & & \\
Sethocapsa (?) sp. & & & & + & & \\
Sphaerostylus lanceola & + & + & & + & & \\
Triactoma (?) sp. & + & + & & & & \\
Zhamoidellum (?) sp. & + & + & & & & \\
\hline
\end{tabular}



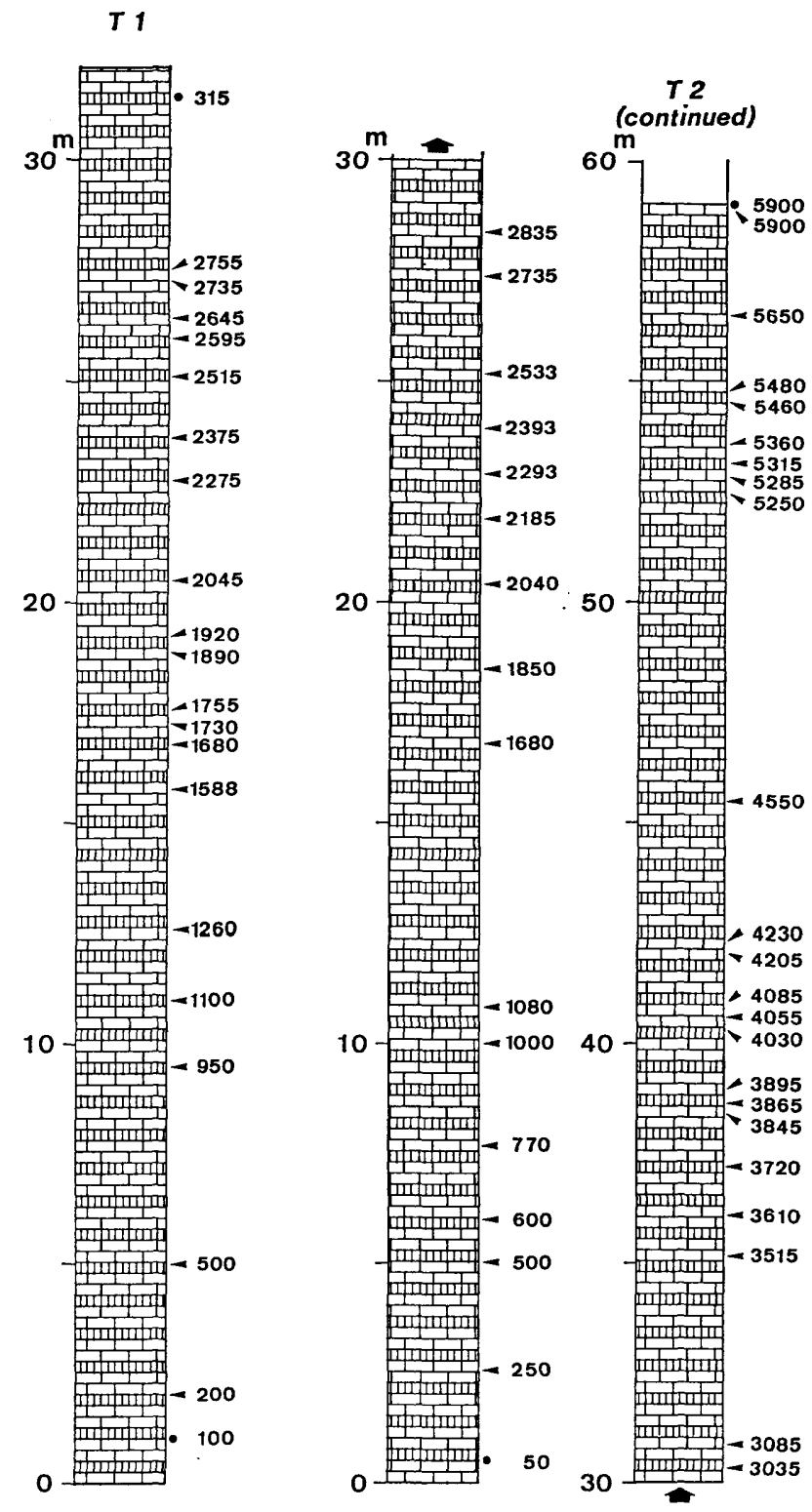

Fig. 7-2. 


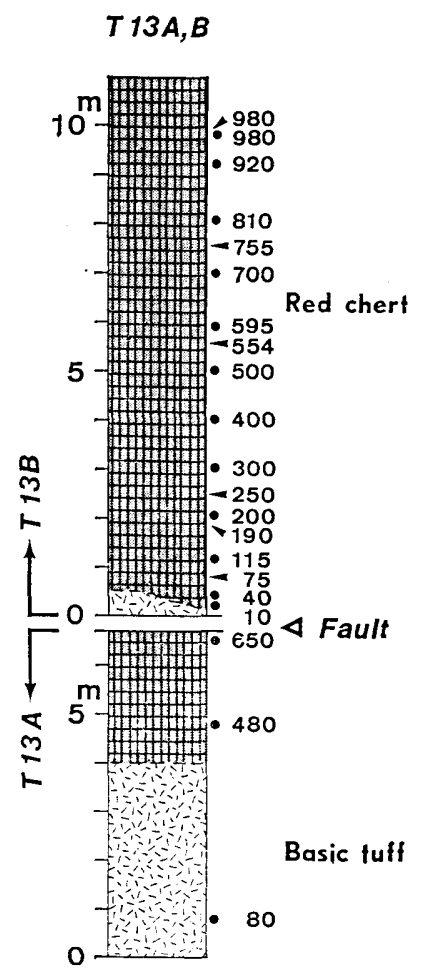

Fig. 8. Lithologic columns of the sections T 13A and B (refer to Fig. 4 for the position of each section).

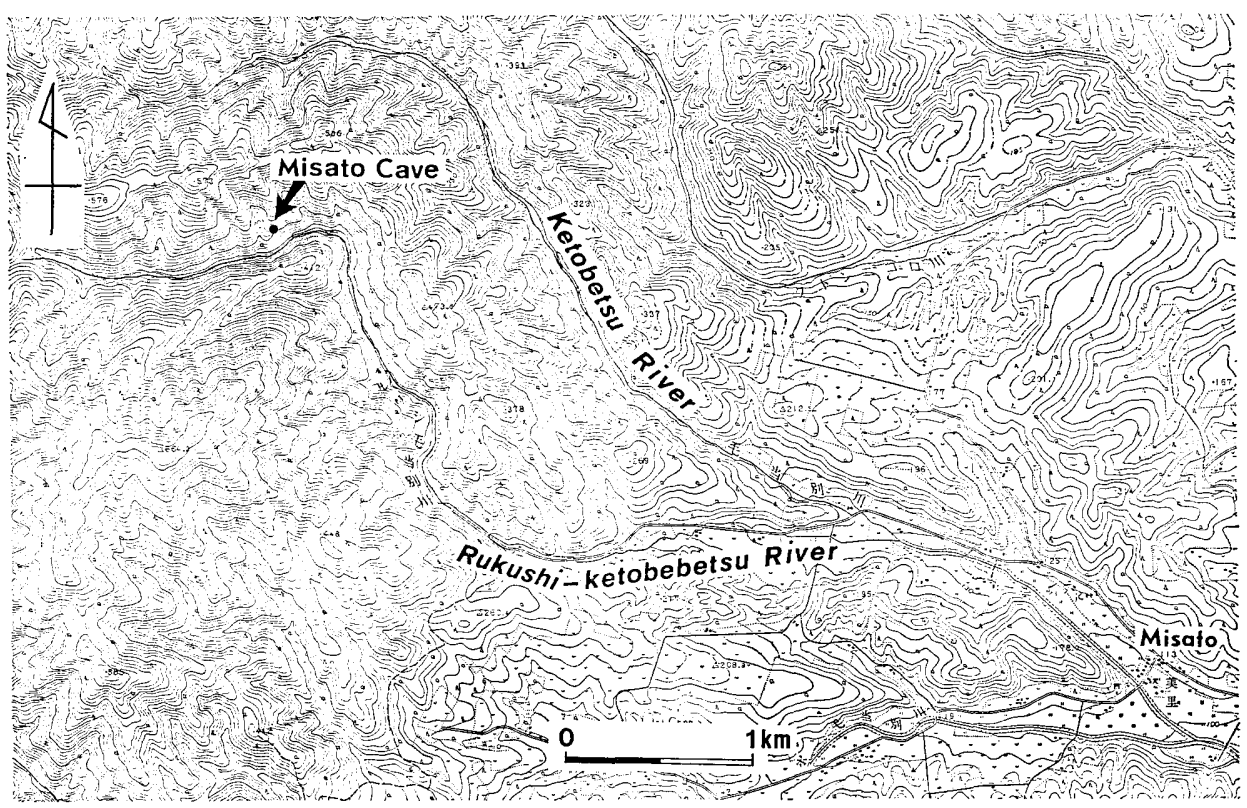

Fig. 9. Index map showing the location of Misato Cave. 


\section{$T 12$}

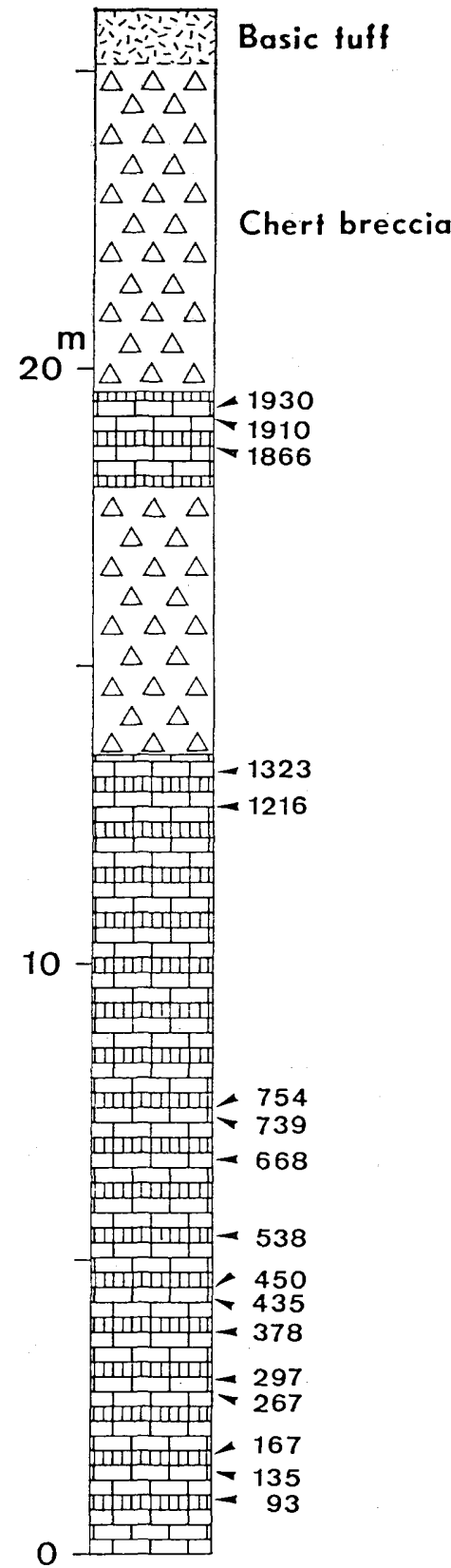

\section{$T 12 A$}

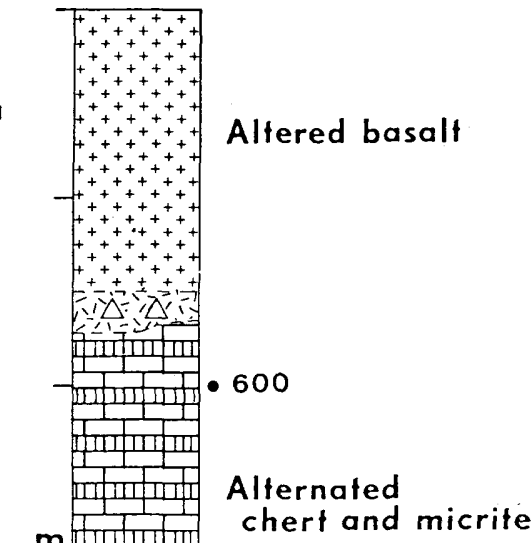

5

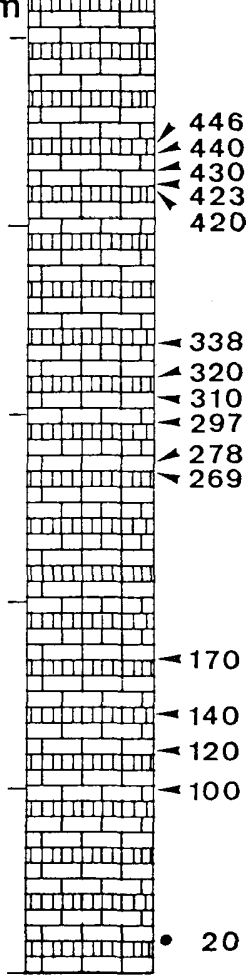

Fig. 10. Lithologic columns from the Misato Cave showing the stratigraphic position of the examined samples. 
Table 2. Radiolarian assemblages from Sections $T 13 A$ and $T 13 B$ from the Chirai Quarry

\begin{tabular}{|c|c|c|c|c|c|c|c|}
\hline species & $\begin{array}{c}\mathrm{T} 13 \\
\mathrm{~A} \\
80\end{array}$ & $\begin{array}{l}\text { T13 } \\
480\end{array}$ & $\begin{array}{l}\text { T } 12 \\
650\end{array}$ & $\begin{array}{c}\text { T13 } \\
\mathbf{B}\end{array}$ & $\begin{array}{l}\text { T } 13 \\
\text { B } \\
40\end{array}$ & $\begin{array}{c}\text { T13 } \\
\mathbf{B} \\
115\end{array}$ & $\begin{array}{l}\text { T } 13 \\
B \\
200\end{array}$ \\
\hline Alievium cf. helenae & & & & + & & & \\
\hline Amphipyndax durisaeptum & & + & + & & & & \\
\hline $\begin{array}{l}\text { Archaeodictyomitra sp. aff. } A . \\
\text { suzukii }\end{array}$ & & + & + & + & + & & \\
\hline Archaeodictyomitra sp. & & & + & + & & & + \\
\hline Archaeospongoprunum cf. imlayi & & + & + & + & & & \\
\hline Archaeospongoprunum sp. & & & & & & + & \\
\hline Cinguloturris carpatica & & & & & + & & \\
\hline Cyrtocapsa (?) sp. aff. C. kisoensis & & + & & & & & \\
\hline Emiluvia cf. orea & & + & + & & & & \\
\hline Eucyrtidiellum ptyctum & & + & + & + & & & \\
\hline Eucyrtidium (?) sp. & & & + & + & & & \\
\hline Eucyrtis cf. hanni & & + & + & + & & + & \\
\hline Haliodictya cf. hojnosi & & + & & + & & & \\
\hline Hsuum cf. brevicostatum & & & + & + & & + & \\
\hline Hsuum (?) sp. aff. H. stanleyensis & & & + & + & + & & \\
\hline Lithelius (?) sp. & & & + & + & & & \\
\hline Mirifusus cf. guadalupensis & & + & + & & & & \\
\hline Mirifusus cf. mediodilatatus & & & + & + & & + & \\
\hline Obesacapsula morroensis & & & + & & & & \\
\hline Paronaella (?) purisimaensis & & & + & & & & \\
\hline Paronaella cf. pygmaea & & & & + & & & \\
\hline Parvicingula cf. boesii & & & + & + & + & & \\
\hline Parvicingula cf. dhimenaensis & & + & + & + & + & & \\
\hline Protunuma sp. & & & + & & & & \\
\hline Ristola cf. procera & & & & & & + & \\
\hline Saitoum cf. pagei & & & + & + & & & \\
\hline Sethocapsa sp. & & & & & & & + \\
\hline Sethocapsa cf. funatoensis & & & & & + & & \\
\hline Spongocapsula cf. palmerae & & & + & + & & & \\
\hline Spongocyclia (?) sp. aff. S. trachodes & & + & + & + & & + & \\
\hline Spongodiscus (?) sp. & & & + & + & & & \\
\hline Spongurus (?) sp. & + & + & & & & & \\
\hline Stichocapsa cf. decora & & & & + & & & \\
\hline Stichocapsa naradaniensis & & + & & + & & & \\
\hline Stichomitra (?) cf. tairai & & & + & & & & \\
\hline Triactoma blakei & & & + & + & & & \\
\hline Triactoma cf. jonesi & & & + & + & & & \\
\hline Triactoma sp. & & & + & + & + & & \\
\hline Tricolocapsa (?) sp. & & + & + & + & & & \\
\hline Zhamoidellum mikamense & + & & + & + & & & \\
\hline
\end{tabular}


Table 3. Radiolarian assemblages from Section T12 from the Masato Cave

\begin{tabular}{|c|c|c|}
\hline \begin{tabular}{|ll} 
species & sample number \\
\end{tabular} & $\mathrm{T} \frac{12}{20}$ & $\begin{array}{r}\mathrm{T} 12 \\
600\end{array}$ \\
\hline Amphipyndax tsunoensis & + & \\
\hline Andromeda sp. & + & \\
\hline Archaeodictyomitra cf. mirabilis & + & \\
\hline Archaeodictyomitra cf. suzukii & + & \\
\hline $\begin{array}{l}\text { Archaeodictyomitra sp. aff. } A \text {. } \\
\text { suzukii }\end{array}$ & + & \\
\hline Archaeospongoprunum cf. imlayi & + & + \\
\hline Crucella sp. & + & \\
\hline Cyrtocapsa (?) cf. kisoensis & + & + \\
\hline Diacanthocapsa sp. & + & \\
\hline Eucyrtis (?) cf. hanni & + & \\
\hline Eucyrtis cf. molengraaffi & + & + \\
\hline Lithelius (?) sp. & + & \\
\hline Obesacapsula morroensis & + & + \\
\hline Paronaella cf. pygmaea & + & \\
\hline Parvicingula $\mathrm{cf}$. boesii & & + \\
\hline Parviciugula cf. dhimenaensis & & + \\
\hline Parvicingula (?) sp. & + & + \\
\hline Patulibracchium sp. & & + \\
\hline Podobursa (?) sp. & + & + \\
\hline Praeconocaryomma (?) sp. & + & \\
\hline Ristola cf. procera & & + \\
\hline Sethocapsa funatoensis & + & \\
\hline Spongocapsula cf. palmerae & + & \\
\hline Spongocyclia (?) sp. aff. S. trachodes & + & + \\
\hline Stichocapsa naradaniensis & & + \\
\hline Stichocapsa pseudodecora & + & + \\
\hline Stichomitra (?) cf. tairai & + & \\
\hline Stichomitra (?) takanoensis & + & \\
\hline Tetratrabus cf. bulbosa & & + \\
\hline Theocorys (?) sp. aff. T. renzae & & + \\
\hline Tricolocapsa spp. & + & + \\
\hline
\end{tabular}

mikamense was identified (Table 2).

In sample $\mathrm{T}$ 13A-480, radiolarians are abundant and fairly well-preserved. Common radiolarian species include Archaeospongoprunum cf. imlayi, Mirifusus cf. guadalupensis, Eucyrtidiellum ptyctum, Eucyrtis cf. hanni, Amphipyndax durisaeptum, and Archaeodictyomitra sp. aff. A. suzukii.

Sample T 13A-650 contains very abundant and well-preserved radiolarians (Plates 31,32), of which common species are Archaeospongoprunum cf. imlayi, Triactoma cf. jonesi, Emiluvia cf. orea, Spongocyclia(?) sp. aff. S. trachodes, Lithelius(?) sp., Archaeodictyomitra sp. aff. A. suzukii, Eucyrtidiellum ptyctum, Eucyrtis cf. hanni, Hsuum cf. brevicostatum, Stichomitra(?) tairai, Mirifusus 
guadalupensis, Obesacapsulla morroensis, Zhamoidellum mikamense and others. d. Section $T 13 B$ (Fig. 8)

12 samples from this section were analyzed for radiolarians, of which only four were rich in well-preserved radiolarians (Table 2).

Sample T 13B-10 contains well-preserved abundant radiolarians (Plates 31, 32). Important species include Archaeospongoprunum cf. imlayi, Tiriactoma blakei, Haliodictya cf. hojnosi, Spongocyclia(?) sp. aff. S. trachodes, Saitoum cf. pagei, Hsuum cf. brevicostatum, Eucyrtidiellum ptyctum, Eucyrtis cf. hanni, Mirifusus mediodilatatus group, Spongocapsula cf. palmerae, Archaeodictyomitra sp. aff. A. suzukii, and Zhamoidellum mikamense.

Sample T 13B-40 yields less abundant but well-preserved radiolarians. They include as dominant species Sethocapsa cf. funatoensis, Archaeodictyomitra sp. aff. A. suzukii, Cinguloturris cf. carpatica, Parvicingula cf. dhimenaensis and so on.

Sample T 13B-115 contains much less abundant but well-preserved radiolarians. They are chiefly Archaeospongoprunum sp., Mirifusus mediodilatatus groups, Eucyrtis cf. hanni, Ristola cf. procera and Parvicingula cf. dhimenaensis.

Sample $\mathrm{T} 13 \mathrm{~B}-200$ is rather poor in abundance and preservation of radiolarian fossils, in which Archaeodictyomitra sp. and Sethocapsa sp. were recognized.

To sum up, among the examined samples from the Chirai sections only four samples $T$ 13A-480, T 13A-650, T 13B-10 and T 13B-40 presented well-preserved radiolarians. The faunal characteristics of radiolarians from these samples are almost similar to each other. That is, the faunal assemblages are characterized

\section{Explanation of Plate 31}

Scanning electron micrographs of radiolarians. Scale bar in all figures $=100 \mu \mathrm{m}$.

Fig. 1. Triactoma cf. T. jonesi PEssagno T 13B-10

Fig. 2. Actinommid gen. et sp. indet. T $12-600$

Fig. 3. Emiluvia cf. E. orea BAUMgartner T $13 \mathrm{~A}-650$

Fig. 4. Patulibracchium sp. T $12-600$

Fig. 5. Spongocyclia (?) sp. aff. S. trachodes RENZ T $13 \mathrm{~A}-650$

Fig. 6. Spongodiscus (?) sp. T 13B-10

Fig. 7. Lithelius (?) sp. T $12-600$

Fig. 8. Zhamoidellum mikamense AITA T $13 \mathrm{~A}-650$

Fig. 9. Eucyrtidiellum ptyctum (RIEDEL \& SANFILIPPO) $\mathrm{T}$ 13B-10

Fig. 10. Obesacapsula morroensis Pessagno T 13A-650

Fig. 11. Mirifusus cf. M. guadalupensis Pessagno T $13 \mathrm{~A}-650$ 


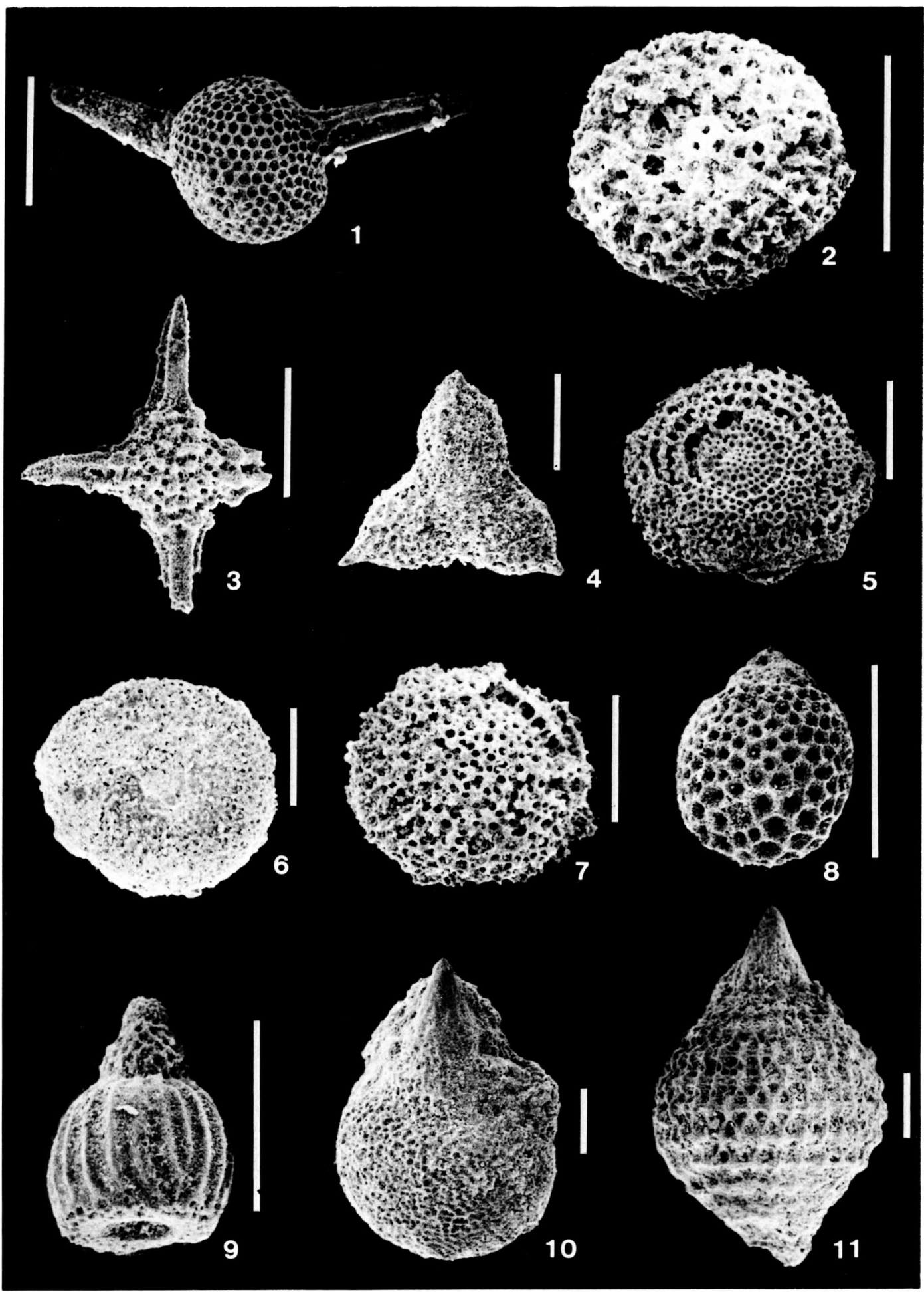

H. OKADA et al.: Microfossil Assemblages from the Nikoro Pelagic Sediments 

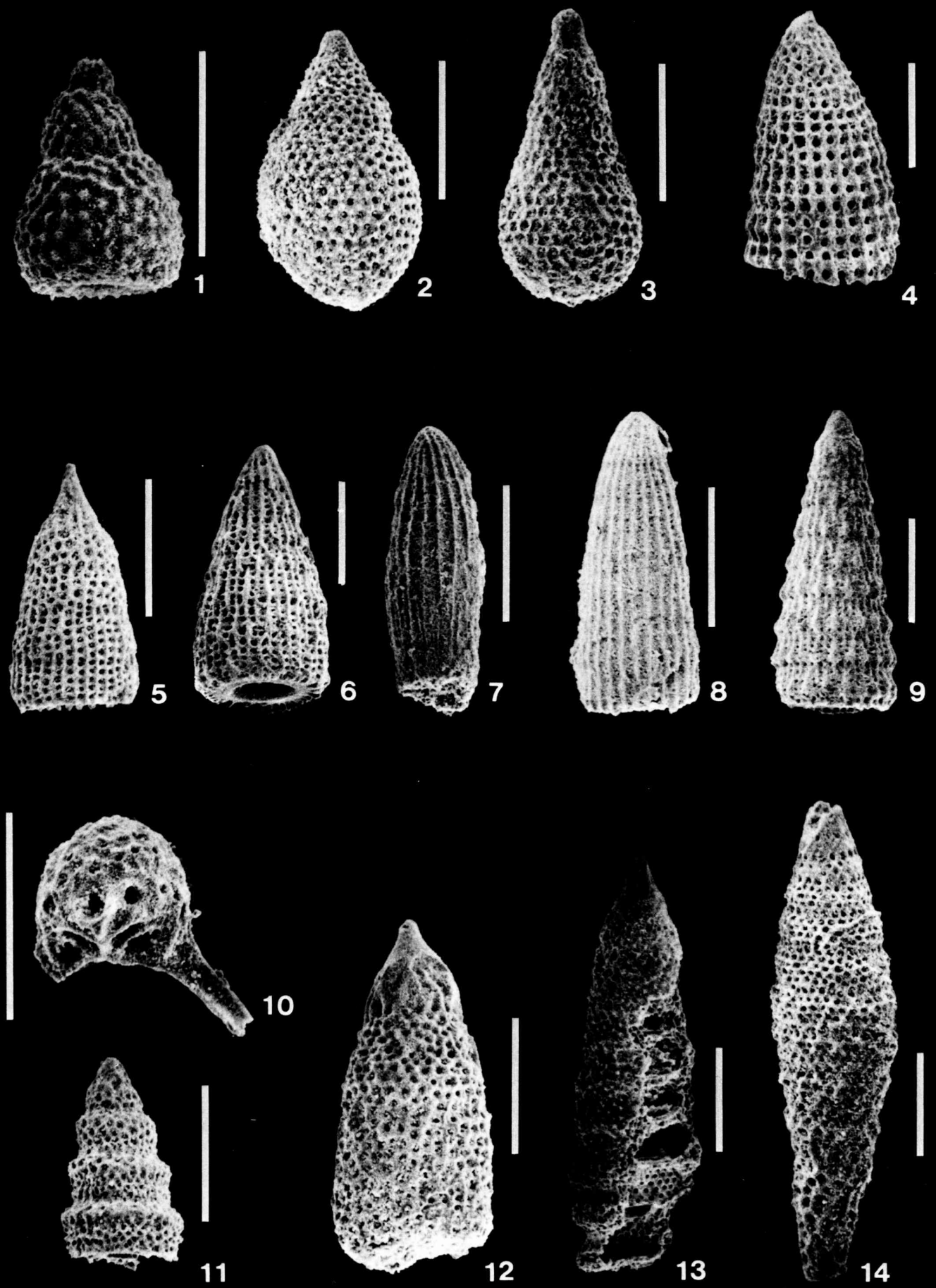

H. OKADA et al.: Microfossil Assemblages from the Nikoro Pelagic Sediments 
by Archaeospongoprunum cf. imlayi, Eucyrtidiellum ptyctum, Hsuum cf. brevicostatum, Archaeodictyomitra sp. aff. A. suzukii, Spongocapsula cf. palmerae and Zhamoidellum mikamense. This assemblage corresponds to the A0 to C2 Zones of the BAUMGaRTNER's (1984) radiolarian zonation and to the Archaeodictyomitra (?) mirabilis Zone to Zhamoidellum mikamense Zone by AITA (1987). In addition to this, Emiluvia orea from T13A-480 and -650 characterizes Zones B and C2 of BAUMGARTNER (1984). Thus, the radiolarian assemblage indicates the age of the Late Oxfordian to Kimmeridgian or to Tithonian.

\section{Misato Cave}

About 30 samples were collected for radiolarian analysis from two sections at the Misato Cave (Figs. 9, 10). Two samples T $12 \mathrm{~A}-20$ and -600 yield abundant well-preserved radiolarian fossils (Table 3, Plates 31,32 ).

Sample $\mathrm{T}$ 12A-20 is rich in well-preserved radiolarians. Dominant species are Archaeospongoprunum cf. imlayi, Paronaella cf. pygmaea, Spongocyclia(?) sp. aff. S. trachodes, Lithelius(?) sp., Andromeda sp., Archaeodictyomitra cf. mirabilis, A. cf. suzukii, Obesacapsula morroensis, Stichomitra(?) cf. tairai and so on.

\section{Explanation of Plate 32}

Scanning electron micrographs of radiolarians. Scale bar in all figures $=100 \mu \mathrm{m}$.

Fig. 1. Eucyrtidium (?) sp.

T $13 \mathrm{~A}-650$

Fig. 2. Theocorys (?) sp. aff. T. renzae ScHAAF T $12-600$

Fig. 3. Amphipyndax tsunoensis AITA $\mathrm{T} 12-20$

Fig. 4. Hsuum (?) sp. aff. H. stanleyensis Pessagno T $13 \mathrm{~A}-650$

Fig. 5. Hsuum (?) sp. aff. H. stanleyensis Pessagno T $13 \mathrm{~B}-10$

Fig. 6. Hsuum cf. H. brevicostatum BAUMGARTNER T $13 \mathrm{~A}-650$

Fig. 7. Archaeodictyomitra cf. A. suzukii AitA T $12-20$

Fig. 8. Archaeodictyomitra sp. aff. A. suzukii AITA T $12-20$

Fig. 9. Hsuum cf. H. brevicostatum BAUMgartNeR T 13A-650

Fig. 10. Saitoum cf. S. pagei Pessagno T $13 \mathrm{~A}-650$

Fig. 11. Cinguloturris carpatica DUMITRICA T0 $180-185$

Fig. 12. Stichomitra (?) cf. S. tairai AITA T 13A-650

Fig. 13. Spongocapsula cf. S. palmerae Pessagno T $13 \mathrm{~A}-650$

Fig. 14. Eucyrtis cf. E. hanni (TAN SIN HoK) T 13A-650 
Sample T 12A-600 contains less abundant but well-preserved radiolarians. Among them Archaeospongoprunum cf. imlayi, Obesacapsula morroensis, Stichocapsa naradaniensis, S. pseudodecora, Ristola cf. procera and Parvicingula cf. dhimenaensis are important.

The radiolarian assemblage mentioned above is well correlatable to Zones A1 to C2 of BAUMgartner (1984) and to the Amphipyndax tsunoensis Zone to the Zhamoidellum mikamense Zone of AITA (1987). Thus, the geologic age of the studied section is Callovian to Kimmeridgian or to Tithonian.

\section{B. Calcareous nannofossils}

Two limestone samples collected from the Chirai Quarry and one sample from the Misato Cave yield common calcareous nannofossils. All of these nannofossils, however, are heavily overgrown, and their identification to any taxonomic levels are almost impossible except for several robust species. Occurrence of Zeugrhabdotus embergeri in samples $\mathrm{T}$ 3A-105 and $\mathrm{T}$ 12-25-30 indicates an age younger than Middle Kimmeridgian for both the Chirai and Misato limestone units (Table 4). The stratigraphic range of Diazomatolithus lehmanii is placed between Middle Jurassic and Albian (PERCH-NIELSEN, 1985), and rare specimens tentatively identified to this species occur in samples T 3A-105 and T 12-25-30. The possible age of Chirai and Misato limestone units judged by the poorly preserved nannofossils, therefore, is between Kimmeridgian and Albian. If the rare specimens resembling nannoconus are truly Nannoconus sp., the oldest

Table 4. List of calcareous nannofossils from limestones from the Chirai Quarry and the Misato Cave

\begin{tabular}{|c|c|c|c|}
\hline $\begin{array}{ll}\text { species } & \text { sample number } \\
\end{array}$ & T3A-15 & T3A-1 & $-25-30$ \\
\hline Cyclagelosphaera margerelii & $\mathrm{C}$ & $\mathrm{C}$ & C \\
\hline Diazomatolithus sp. cf. D. lehmanii & - & $\mathbf{R}$ & $\mathrm{R}$ \\
\hline Ellipsagelosphaera communis & - & F & $\mathbf{F}$ \\
\hline Nannoconus? sp. & $\mathbf{R}$ & - & - \\
\hline Watznaueria barnesae & A & A & A \\
\hline Zeugrhabdotus embergeri & - & $\mathrm{R}$ & $\mathbf{F}$ \\
\hline
\end{tabular}

A: abundant, $C$ : common, $F$ : few, $R$ : rare

\section{Explanation of Plate 33}

Optical micrographs (cross-polarized light) of calcareous nannoplankton. Scale bar for all figures $=10 \mu \mathrm{m}$.

Fig. 1. Cyclagelosphaera margerelii Nö̈L, sample T3A-105

Fig. 2. Diazomatolithus cf. D. lehmanii Nö̈L, sample T3A-105

Fig. 3. Ellipsagelosphaera communis (Reinhardt) Perch-Nielsen, sample T3A $-105$

Fig. 4. Nannoconus? sp., sample T3A-105

Fig. 5. Watznaueria barnesae (BLACK) Perch-Nielsen, sample T3A-105

Fig. 6. Zeugrhabdotus embergeri (Nö̈L) PERCH-NIELSEN, sample T12-25-30 

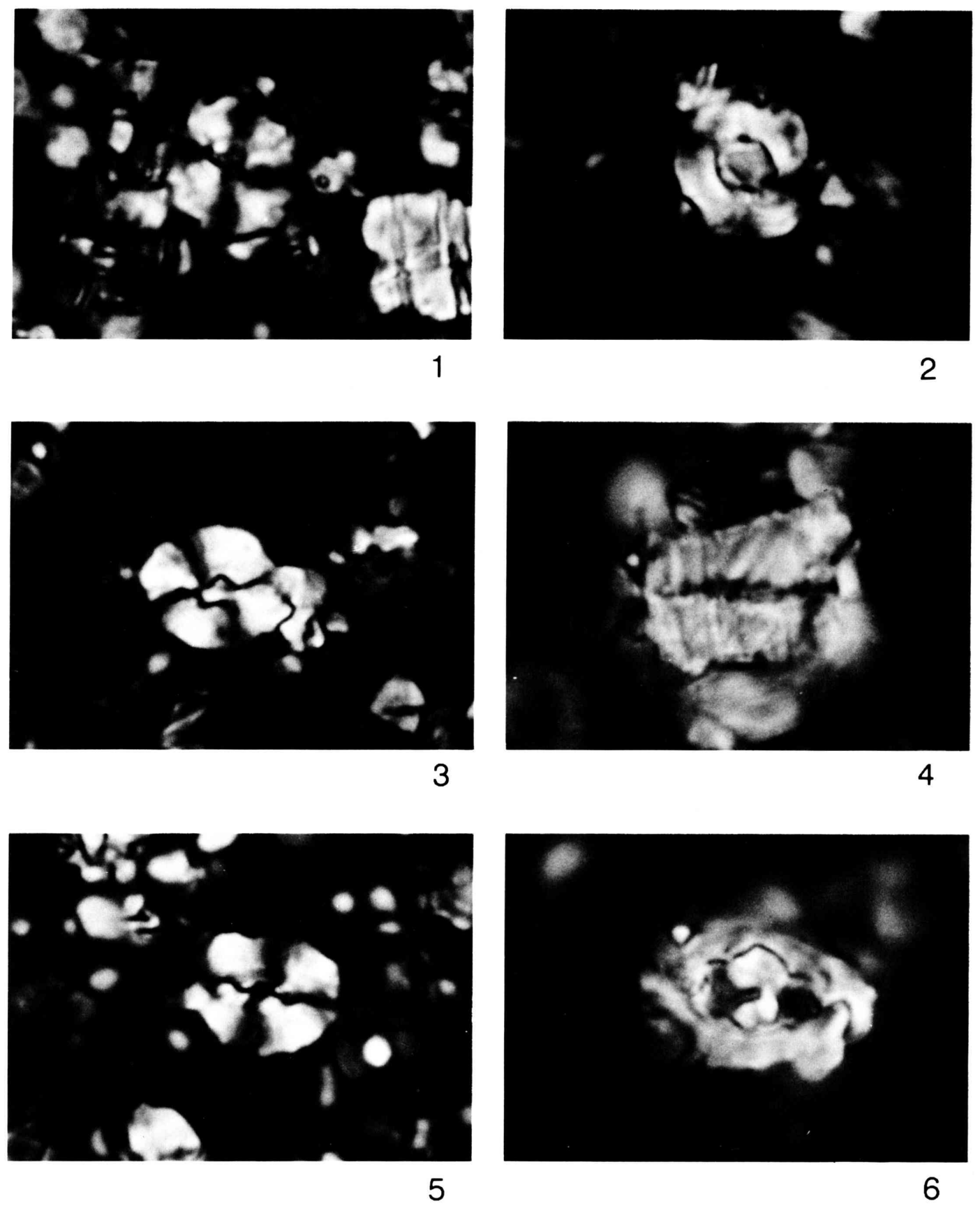

$10 \mu \mathrm{m}$

H. OKADA et al.: Microfossil Assemblages from the Nikoro Pelagic Sediments 

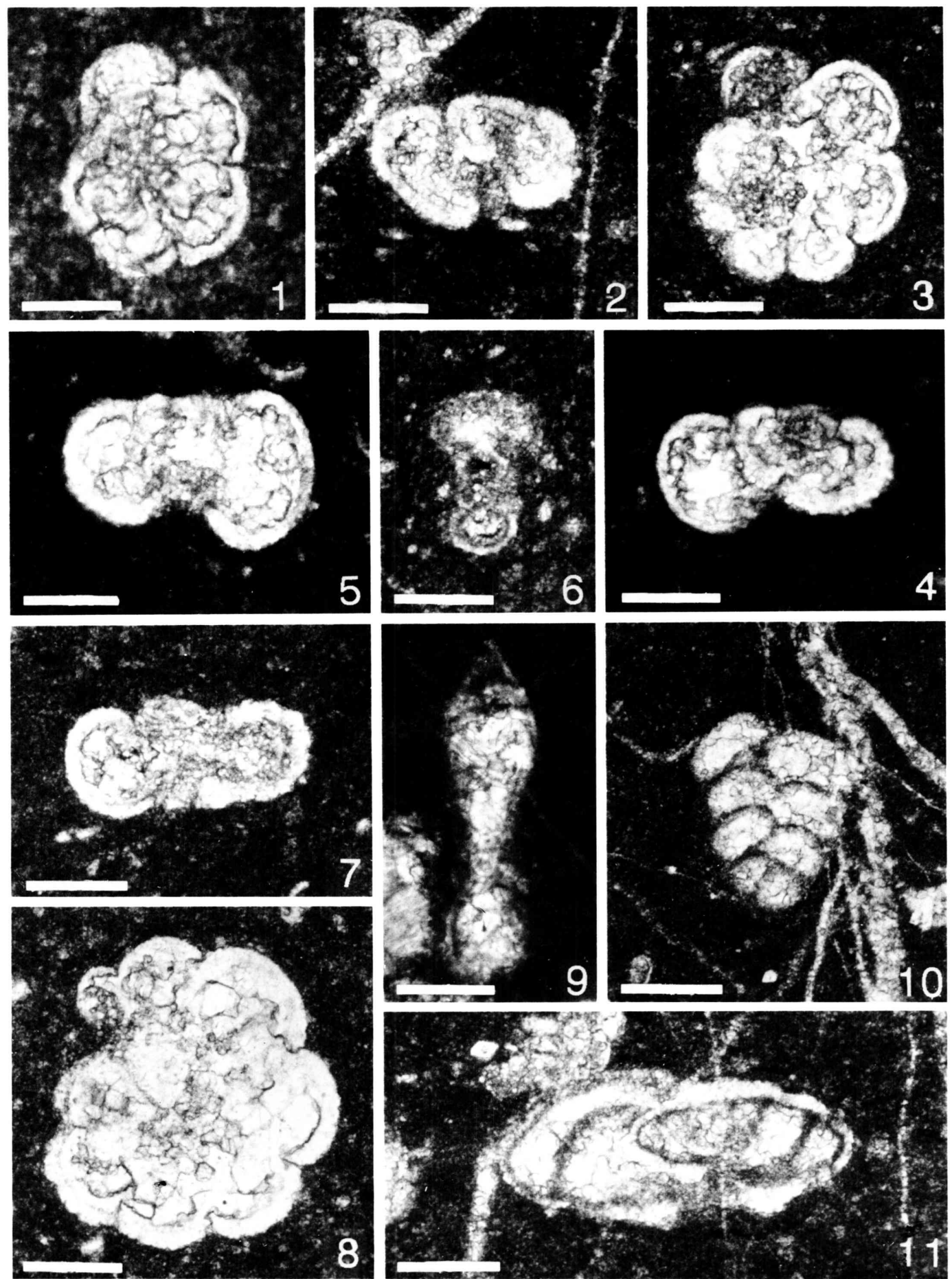

H. OKada et al.: Microfossil Assemblages from the Nikoro Pelagic Sediments 
possible age for the Chirai unit could be late Tithonian.

\section{Foraminifers}

Planktic foraminifers of Aptian age are found in the reddish gray to medium gray stylolitic and veined micritic limestone interbedded with medium to dark gray chert at the Chirai Quarry. The faunas are low to moderately diverse and generally poorly preserved. The oldest samples are assigned to the Globigerinelloides ferreolensis Zone (KS 8) of SLITER (1989) and yield a middle Aptian age (about $116 \mathrm{Ma}$ ). This meager assemblage consists of Globigerinelloides ferreolensis (MOULLADE) and small hedbergellids such as Hedbergella delrionensis (CARSEY), $H$. sigali (MOULLADE) and $H$. similis LONGORIA.

Tectonically juxtaposed to these samples is a sequence of pelagic limestone and chert that contains a diverse assemblage of large, robust planktic foraminifers. The lower samples in this sequence belong to the Hedbergella gorbachikae Zone (KS 10) of late Aptian age (about $115 \mathrm{Ma}$ ). Foraminifers include Hedbergella delrioensis, $H$. gorbachikae LONGORIA, and $H$. trocoidea (GANDOLFI). The sequence extends upward into the Ticinella bejaouaensis Zone (KS 11) of latest Aptian age with the appearances of the nominal marker species. The early samples in this zone contain Planomalina cheniourensis SIGAL and thus indicate an age of about $114 \mathrm{Ma}$. The lack of this species in the uppermost beds assigned to Zone KS 11 suggests an age near the Aptian-Albian boundary at about $113 \mathrm{Ma}$.

The planktonic foraminiferal assemblages from the Chirai Quarry are identical to other coeval open-ocean assemblages. Most notable is the similarity to assemblages from topographic highs in the Pacific Basin such as the midPacific Mountains, Magellan Rise, Ontong-Java Plateau and Manihiki Plateau,

\section{Explanation of Plate 34}

Thin-section photomicrographs of planktonic foraminifers. Scale bar $=100 \mu \mathrm{m}$ for Figs. 2, 3, 4, 5, 6, 7, 8, 9, 11; 50 $\mu \mathrm{m}$ for Fig. 1; and $250 \mu \mathrm{m}$ for Fig. 10.

Fig. 1. Hedbergella delrioensis (CARSEY), transverse section, sample T3A-11, Zone KS 11 (SLITER, 1989)

Fig. 2. Hedbergella gorbachikae LONGORIA, axial section, sample T3A-17, Zone KS 10 (SLITER, 1989)

Figs. 3, 4. Hedbergella trocoidea (GANDoLFI)

3. Transverse section, sample T3A-10, Zone KS 11 (SLITER, 1989)

4. Axial section, sample T3A-1, Zone KS 10 (SLITER, 1989)

Fig. 5. Ticinella roberti (GANDoLFI), axial section, sample T3A-13, Zone KS 11 (SLITER, 1989)

Fig. 6. Globigerinelloides barri BoLLI, LoEBLICH and TAPPAN, axial section, sample T3A-17, Zone KS 10 (SLITER, 1989)

Figs. 7-8. Ticinella bejaouaensis SigAL, sample T3A-10, Zone KS 11 (SLITER, 1989)

7. Axial section

8. Transverse section

Fig. 9. Planomalina cheniourensis SigaL, axial section, sample T2-5360, Zone KS 11 (SLiter, 1989)

Fig. 10. Dorothia sp., axial section, sample T3A-18

Fig. 11. Gavelinella sp. axial section, sample T3A-11, Zone KS 11 (SLITER, 1989) 


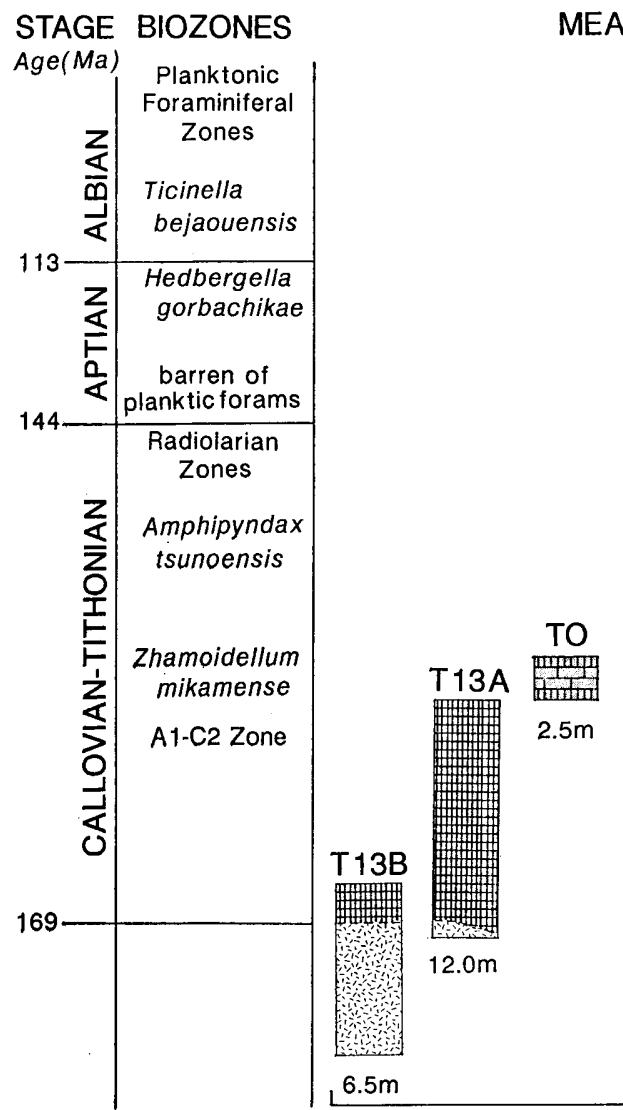

MEASURED STRATIGRAPHIC SECTIONS
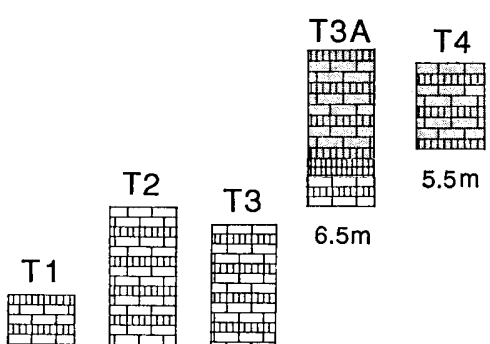

min

$32.0 \mathrm{~m} 59.0 \mathrm{~m}$
$\mathrm{T} 12$

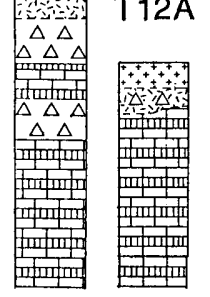

$26.0 \mathrm{~m} \quad 8.0 \mathrm{~m}$
RECONSTRUCTED LITHOLOGY OF THE CHIRAI SECTION

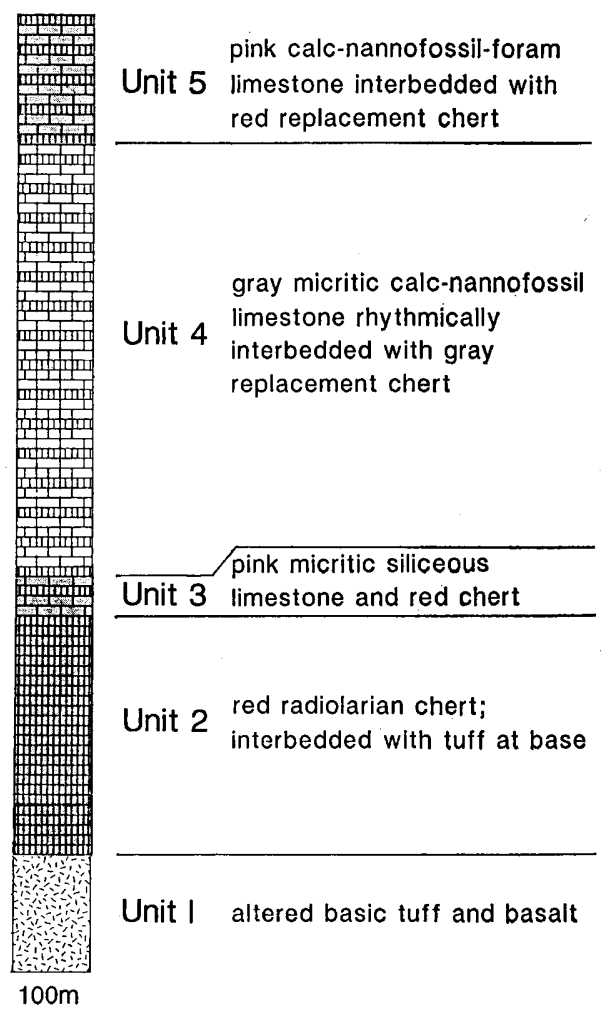

Fig. 11. Correlation of the measured stratigraphic sections. Planktonic foraminiferal zonation after SLITER (1989) and radiolarian zonation after BAUMGARTNER (1984) and AITA (1987). 
and to pelagic limestone of the Franciscan Complex accreted to the western margin of the United States (SLITER, 1989, in press). In addition, the assemblages are strongly similar to those from pelagic limestone in Italy (ARTHUR and Premoli Silva, 1982).

Benthic foraminifers from the limestone at the Chirai Quarry indicate bathyal water depths of about $1000 \mathrm{~m}$ and above the calcite compensation depth. Rare calcareous and agglutinated species are present and the assemblage is dominated by Gavelinella and Dorothia with lesser occurrence of Dentalina, Gaudryina, Gyroidinoides, Lenticulina, Spiroplectammina among others. Other biogenic material includes poorly preserved and recrystallized radiolarians, and occasional fish debris. The lack of shallow-water biogenic material indicates that the site of deposition was deeply submerged or far removed from a shallow source.

\section{Concluding Remarks}

\section{A. Age and stratigraphy}

The age of the Tokoro rocks has been studied by many workers. For the Nikoro Group, in particular, Kiminami et al. (1983) and IWATA et al. (1983) reported radiolarians denoting Late Jurassic (Kimmeridgian-Tithonian) to Early Cretaceous (Berriasian-Aptian). Our present study has also confirmed this notion about the age of the Nikoro Group, as summarized below.

Radiolarian assemblages from both the Chirai Quarry and Misato Cave sections show common features with each other, and that from the lower sequence of the Chirai section is correlatable with BAUMGarTnER's (1984) B to C2 Zone indicating the Late Oxfordian to Tithonian age. Furthermore, planktonic foraminifers from the upper sequence of the Chirai Quarry suggest a late Aptian to early Albian age.

Therefore, the studied section at the Chirai Quarry is reorganized into a composite stratigraphic sequence as shown in Fig. 11. This sequence consists of 5 units, $\mathrm{I}$ to $\mathrm{V}$ in ascending order. Unit I comprises altered basic tuff and basalt, Unit II is composed of red bedded chert, Unit III is represented by pink micritic siliceous limestone and red chert, Unit IV consists of gray micritic limestone rhythmically interbedded with gray replacement chert, and Unit V accommodates pink limestone interbedded with replacement chert.

The Misato section is correlated with the Chirai section as shown in Fig. 11. This stratigraphy implies that the sediments were deposited on the ocean floor under the influence of sedimentation on sea mounts.

\section{B. Origin of oceanic sediments}

Oceanic sediments exposed in the Tokoro Belt are represented by rhythmically interbedded micritic limestone and chert, both of which yield microfossils. The presence of nannofossils indicates that the limestone was originally calcareous nanno-ooze. The occurrence of limestone and the lack of either terrigenous debris or shallow-water bioclasts indicate that these sediments were initially deposited 
in the deep ocean (above the CCD) far distant from continental margins. Benthic foraminifers from the limestone indicate bathyal environments of about $1000 \mathrm{~m}$ deep and above the CCD. Limestones from other localities in the Tokoro Belt, however, contain oolites and coralline debris (for example, some limestone bodies, south of Kunneppu), which indicate shallow-water environments. Thus, a seamount environment formed near an oceanic ridge as suggested for the Nikoro Complex by SAKAKIBARA et al. (1986), is consistent with our observation.

According to our paleomagnetic study of the Nikoro limestone and chert sections, the blocks show a mean inclination of $\mathrm{I}=3.4^{\circ}$, corresponding to a paleolatitude ranging from $5^{\circ} \mathrm{N}$ to $9^{\circ} \mathrm{S}$ for Callovian to Aptian times (168-112 Ma) (TARDUNO et al., 1988).

Therefore, we suggest that the Nikoro rocks were formed in a seamount environment near a spreading ridge or a hotspot in the paleoequator region on the Izanagi Plate. Later northward migration of the Nikoro rocks may be explained according to the models of ENGEBRETSON et al. (1984) and HENDERSON et al. (1984). More detailed discussions on the plate tectonics interpretation of the Nikoro ophiolites will be given separately (TARDUNo et al., in press).

A further similarity of the limestone in this area to that of the Franciscan Complex of northern California is found in the degree of stylolitization, recrystallization, chertification and veining that clearly differentiates these limestones from those from sites in the Pacific sites or from sections in Italy (SLITER, 1990, in press). This similarity suggests a like tectonic history for the Tokoro deposits that would involve the accumulation and disruption of a subduction complex. Indeed, the Tokoro deposits themselves, like those of the Franciscan Complex, presumably represent the obducted carbonate caps of Cretaceous plateaus that were originally deposited beneath a low-latitude paleoequatorial productive zone.

\section{Acknowledgments}

Our sincere thanks are due to Prof. Takeo Bamba, Dr. Keiji Iwata and Dr. Jun TAJIKA for their help in the identification of suitable sample localities, to Dr. Koji Yagishita and Mr. Xiaoli Guo for their assistance in the field, and to Messrs. Hideo KIDO and Tomindo SATo of the Japan Petroleum Exploration Co. Ltd. (JAPEX, Sapporo Office) for field support in Hokkaido. We are indebted to Dr. Hiroyoshi SANO for his kind help in preparing the photomicrographs for Plate 30 and for his review of the manuscript with constructive comments.

This work has been supported in part by a Grant-in-Aid for the Scientific Research from the Ministry of Education, Science and Culture (Mombusho) to OKADA, and in part by a Harold T. Stearns Fellowship Award, Geological Society of America Research Grant, Sigma Xi Research Grant, and Stanford University Kauffman Research Award to TARDUNo.

\section{References}

AItA, Yoshiaki (1987): Middle Jurassic to Lower Cretaceous radiolarian biostratigra- 
phy of Shikoku with reference to selected sections in Lombardy Basin and Sicily. Tohoku Univ., Sci. Rep., 2nd Ser. (Geol.), 58, (1), 1-91.

Arthur, M. A. and Premoli Silva, I. (1982): Development of widespread organic carbon-rich strata in the Mediterranean Tethys. In SchlANGER, S. O. and CiTA, M. B., eds., Nature and Origin of Cretaceous Carbon-rich Facies. 7-54, Academic Press, London.

BAmba, Takeo (1984): The Tokoro Belt, a tectonic unit of the central axial zone of Hokkaido. Jour. Fac. Sci., Hokkaido Univ., Ser. IV, 21, (1), 21-75.

BAUMgartNeR, P. O. (1984): A Middle Jurassic-Early Cretaceous low-latitude radiolarian zonation based on unitary associations and age of Tethyan radiolarites. Eclogae Geol. Helv., 77, (3), 729-837.

Engebretson, D. C., Cox, A. and Gordon, R. C. (1984) : Relative motions between oceanic plates of the Pacific basin. Jour. Geophys. Res., 89, 10291-10310.

Henderson, L. J., Gordon, R. G. and Engebretson, D. C. (1984) : Mesozoic aseismic ridges on the Farallon plate and southward migration of shallow subduction during the Laramide Orogeny. Tectonics, 3, (2), 121-132.

Iwata, Keiji, Watanabe, Masato, Nakamura, Koji and Uozumi, Satoru (1983) : Occurrence of Jurassic and Cretaceous radiolarians from the pre-Tertiary systems around Lake Saroma, Northeast Hokkaido. Earth Sci., 37, (4), 225-228. (in Japanese)

Kiminami, Kazuo and Kontani, Yoshihiro (1983): Mesozoic arc-trench systems in Hokkaido. In HASHimoto, Mitsuo and UYEDA, Seiya, eds., Accretion Tectonics in the Circum-Pacific Regions. 107-122, TERRAPUB, Tokyo.

-, SuIzu, Masahiro and Kontani, Yoshihiro (1983): Discovery and significance of Cretaceous radiolarias from the Mesozoic in the Tokoro Belt, eastern Hokkaido, Japan. Earth Sci., 37, (1), 48-52. (in Japanese)

Kontani, Yoshihiro and Kiminami, Kazuo (1980) : Petrological study of the sandstones in the pre-Cretaceous Yubetsu Group, northeastern Hidaka Belt, Hokkaido, Japan. Earth Sci., 34, (6), 307-319.

- — TAJiKa, Jun and MaNiwa, Ken (1986): Cretaceous sedimentary rocks in the Tokoro and Nemuro belts, Hokkaido. Monogr. Assoc. Geol. Collab. Japan, (31), 157-171. (in Japanese with English abstract)

OKADA, Hakuyu (1982): Geological evolution of Hokkaido, Japan: an example of collision orogenesis. Proc. Geol. Assoc., 93, (2), 201-212.

Perch-Nielsen, K. (1985) : Mesozoic calcareous nannofossils. In Bolli, H., SaUnders, J. B. and Perch-Nielsen, K., eds., Plankton Stratigraphy. 329-426, Cambridge Univ. Press.

Sakakibara, Masayuki, NiIda, Kiyoshi, Toda, Hideaki, Kito, Norio, Kimura, Gaku, Tajika, Jun, КатоH, Takayuki, Yoshida, Akihiko and Research Group of THE ToKoRo BELT (1986) : Nature and tectonic history of the Tokoro belt. Monogr. Assoc. Geol. Collab. Japan, (31), 173-187. (in Japanese with English abstract) and TANAKA, Keisaku (1986) : Discovery of inoceramus from the Saroma Group, the Tokoro Belt, northeastern Hokkaido. Earth Sci., 40, (3), 205-206. (in Japanese)

SLITER, W. V. (1989) : Biostratigraphic zonation for Cretaceous planktonic foraminifers examined in thin section. Jour. Foraminiferal Res., 19, (1), 1-19. (1989, in press): Aptian anoxia in the Pacific Basin. Geology.

(1990, in press): Cretaceous planktonic foraminiferal biostratigraphy and paleoceanographic events in the Pacific Ocean with emphasis on indurated sediments. Centenary of Japanese Micropaleontology-Testimonial Volume for Dr. Yokichi TAKayanagi, Sendai.

TAJIKA, Jun (1988): Stratigraphy and structure of the Upper Cretaceous Yubetsu Group, Tokoro Belt, eastern Hokkaido-an application of trench accretion model-. Jour. Geol. Soc. Japan, 94, (11), 817-836. (in Japanese with English abstract) 
Tarduno, J. A., Okada, Hakuyu, Sliter, W. V., McWilliams, Michael, Nakaseko, Kojiro, NISHIMURA, Akiko and OKADA, Hisatake (1988): The Tokoro Belt: a far-traveled oceanic terrane of Hokkaido, Japan. 1988 DELP Tokyo Intern. Symp. DELP Publ., (22), 38. 